\title{
Involuntary Resettlement: From a Landslide-Affected Slum to a New Neighbourhood. Case Study of Mina Resettlement Project, Ahvaz, Iran
}

\author{
Mozaffar SARRAFI 1, Alireza MOAHMMADI 2 \\ 1 University of Shahid Beheshti, Faculty of Architecture and Urban Planning, Department of Urban Planning, Tehran, IRAN \\ 2 University of Mohaghegh Ardabili, Faculty of Humanities, Department of Geography and Planning, Ardabil, IRAN \\ E-mail: sarrafi@sbu.ac.ir, a.mohammadi@uma.ac.ir \\ DOI: 10.24193/JSSP.2018.1.02 \\ https://doi.org/10.24193/JSSP.2018.1.02
}

K e y w o r d s: involuntary resettlement, slum, landslide, Mina Resettlement Project (MRP)

\begin{abstract}
A B S T RA C T
Involuntary resettlement approach to take care of slums settlement is rarely carried out in Iran. One of these rare experiences is Mina Resettlement Project in Ahvaz city which was implemented from 2005 to 2009. This article evaluated the goals of Mina Resettlement Project. Extensive interviews with Mina Resettlement Project authorities were conducted. Also, 35 questionnaires from displaced households were used for data collection. Criteria including environmental, physical, social, economic, infrastructures, and public services were used to evaluate the impact of the Mina Resettlement Project on the local community. To analyze this data, GoalsAchievement Matrix and "Criteria, Options, Weight, Score" techniques were employed. Mapping and cartographic materials were produced by using ArcGIS software. Findings indicate the different impacts of the project on the quality of life of the relocated households. The environmental and physical goals were successfully achieved, but the socioeconomic goals were not realized. Therefore, Mina Resettlement Project proves to be not quite a successful experience and ought not to be replicated without associating socioeconomic project for the community resettled.
\end{abstract}

\section{INTRODUCTION}

In 2014, it was estimated that about one billion people of the world's population lived in urban slums; of which about $90 \%$ resided in the cities of Global South [1], [2]. This figure is about $43 \%$ of Iranian and $30 \%$ of Asian cities, respectively [3], [4], [5]. In the 1960s, the Iranian government began to cope with the slum problem mainly through slum clearance and eviction; Irandoost, K. (2009), meanwhile, the resettlement approach was trivial [6]. Since 2003 and with the ratification of the National Document on Enabling and Regularizing slums, a new era, which diminished the coercive approaches, began [7]. Accordingly, slums as one category of settlement in Iran are defined as "hastily constructed housing often built by their eventual occupants, mostly without the permit to construct such buildings. They are often outside existing formal planning; and inhabited by lower income groups. Slums are characterised by functional linkages to the main city, low quality of life and desperately low urban services as well as high population density” [7].

Khuzestan with an area of $64 \mathrm{~km}^{2}$ and a population of 4.6 million people [8], is one of Iran's oilrich provinces with notable slums springing forth mainly from the rural-urban migrations since half a century ago. This is due to several factors which include but not limited to the 1960 s land reform, economic restructuring to the benefit of modern industries and 
services in urban areas as well as the shift of rural poverty to urban areas, the Islamic revolution of 1979 and the arising freedom of mobility, the invasion of Iraq in 1980 and its consecutive colossal migration from border areas to major cities. In 2014, over 700,000 persons, which was equivalent to $21.5 \%$ of the urban population of the province, were recorded as residents of slums [9]. Ahvaz metropolis is the capital of Khuzestan with 1.3 million people living on 22,000 hectares; of which about 400,000 are slum dwellers [9], [10]. Ahvaz has witnessed rapid growth of slums in the last decades. Approximately, at a rate of 6,000 persons per year, the population of Ahvaz slum areas increased from 101,581 people in 1976 to approximately 330,000 people in 2013. According to new surveys, 20 slum areas with a total mass area of 3,600 hectares exist in the city with up to 350,000 residents consisting of $15.4 \%$ of the city area and $37 \%$ of the city population [9], [11]. During the last decade, different measures were taken, sometimes concurrently, to cope with the issue; these measures included: site and service, public housing, enabling and upgrading, resettlement and even demolition. The Flagship Project was a resettlement for 5,400 households with generous state's support, still in process [9], [12], [13].

Karoon slum (the beginning experience for the said resettlement project) in the east of Ahvaz city has 14,00o people on a 46-hectare area, located on unstable slopes susceptible to slump and landslide. The natural hazard risk was the primary reason for prioritizing the action plan for this area titled as Mina Resettlement Project (MRP) to assist the local community. However, there were opposing views among city managers, planners and community members about the outcome and the process of implementing the MRP. Based on the MRP documents and field surveys, this article made an effort to recognize the compatibility of goals and objectives with the implementation outputs and assessing the impact of this project on the community life. Cases of resettlement have not been studied previously in Iran and were certainly not acknowledged on the basis of field works with certain data collections. Hence, the case of Ahvaz city can represent such projects in Iran on a general note. Therefore, this research on MRP can be added to the literature, which lacks case studies on Iran. The main purposes of this study were:

a) to introduce the MRP. The authors sort to introduce the MRP to the scientific and professional community as an example of Iran experience in slum resettlement projects.

b) to evaluate the MRP impacts on the resettled persons by analysing living environment dimensions. We tried to analyse the impacts of implementing the MRPon displaced persons;

c) to explore the community satisfaction from the MRP results.
Primarily, this article attempted to answer the questions; has the MRP succeeded in achieving its goals? To what extent has the MRP affected the local community living environment? How much is the satisfaction of the local community after the implementation of MRP?

This is the first study on slum settlement in Iran; prior to this study, no research has put into consideration slum resettlement project until the year 2018.Also, in terms of geographical scope and study population, the study on the resettlement projects has not been carried out. The method used in this study was an innovative method extracted from the combination of Goals Achievement Matrix (GAM) and Criteria, Options, Weight, Score (COWS) methods.

This research can be helpful in the pursuit of further studies, in order to find realistic solutions for community resettlement projects in different developing countries like Iran.

This article is made up of six parts: introduction, theoretical basis and literature review, methodology, findings and discussion, and finally, conclusion.

\section{THEORETICAL BACKGROUND}

It is estimated that 10 million people are displaced by resettlement programs yearly in the world [14]. International experiences demonstrated that insitu slum upgrading in most cases were more effective in improving local community life than resettlement schemes [2]. Nevertheless, in rare cases, involuntary resettlement was inevitably practiced since 1950s, which was taken extensively or limitedly mostly because of the natural hazards risk at the site [15]. Resettlement includes a set of well-thought and methodical actions, based on economic, social, environmental, technical, legal, and financial planning. The goal is not simply to displace people but to change their socio-economic situation to a higher status [15]. The critiques believe that resettlement causes negative outcomes for the relocated community. On the other hand, those in favour say the positive outcomes outweigh the negative outcomes [16]. While the outcomes are not definite, different experiences of UN Human Settlement Program revealed in most cases that the socio-economic and environmental disadvantages of resettlement are more than the advantages, which cause loss of local community assets [17], [2], [15].

A number of researchers have studied the impact of resettlement programs, mostly demonstrating and emphasizing the negative repercussions [18]. Kapse et al (2012), based on their study on India's resettlement programs, concluded that most of these programs have had high costs as compared to in-situ upgrading and failed due to negligence of essential nonphysical factors (e.g., security of tenure, capacity 
building, community cohesiveness) [19]. Therefore, most relocated persons have returned to their previous settlements or moved to other slums and they have rented out their new houses. Purnomo et al. (2013) reached the same conclusion in evaluating resettlement projects of Malang city in Indonesia. They found out that these projects of state did not lead to higher quality of life of the relocated community even after incurring socio-economic costs [20]. But in some cases, resettlement can provide better residential outcomes to resettled dwellers by providing decent homes and proper environment quality [21]. Resettlement may disconnect inhabitants from the hubs of the labour market and intensify their socio spatial isolation [22]. In Patel and Mandhyan (2014) study of resettlement projects of Indore city in India, they concluded that the implementation of these projects was conducive to pauperization of the target community [23]. Gebre (2014) in his research about resettlement projects in Addis Ababa suggested that these projects had very different impacts, both negative and positive, on the conditions of living of the resettled community [18]. World Bank studies (2011) and researchers like Nampungu and Kasabiiti (2009) and Singh (2013) demonstrated that the implementation of resettlement projects may affect the children and old people of the relocated community negatively, particularly with regards to accessing public services and recreational opportunities [24], 25], [26]. Kleinhans and Kearnes (2013), insisted on the effects of relocation on youths and adults [27], while other researchers emphasized on the relocation impacts on children and women [28], [29]. Read (2014), asserted that resettlement may cause slum dwellers to gain citizenship. But, it may create problems for residents from a different neighbourhood commuting to the city centre; because of the time and cost limits [30]. The said researchers have also studied resettlement project for Bujagali Dam project in Uganda [25]. They asserted that it had adverse impacts in terms of employment and security in general, and in children, old and disabled persons' health in particular. World Bank (2010) specified a number of factors for unsuccessful resettlements projects; these included: inappropriate site selection, remoteness from social networks, unsuitable housing design, lack of community participation and deficiencies in financial planning; and recommends the necessity of ex-ante socio-economic and environmental impact assessments [31]. In some cases, resettlement generally suffers from second-rate planning, inadequate consultation and insufficient financing. Resettlement plans are generally cursory in their analysis of social and cultural parameters [32]. Original residents are more willing to resettle due to a higher likelihood of increasing housing value after resettlement projects. Additionally, original residents' willingness to pay for the resettlement is associated with their economic status [33].
Zaman (2002), suggested that any policy for slum resettlement should pay attention to the following: (i) clear definition of involuntary resettlement, compensation, replacement value, loss of assets, loss of income, rehabilitation and assistance; (ii) provision of a land market survey for determining compensation rate; (iii) criteria for defining and identifying project-affected persons; (iv) baseline survey and participatory planning; (v) grievance procedures; (vi) institutional framework for implementation; and (vii) monitoring and evaluation of resettlement by independent agencies [34]. UN-Habitat (2008b) advised that resettlement program should be taken as the last resort in unavoidable hazardous cases of irregular settlements. Various factors including social systems, history, and intra community relations, play a vital role in resettlement projects because social conditions shape each community's decision-making style [35]. Respecting each community's decision-making process is important to preserving their capacity and selfdetermination. Efforts should be made to emphasize the provision of appropriate support to communities in need of assistance when drafting a resettlement plan [36]. The best practices in case of resettlements show the importance of having feasibility studies' terms of reference (TOR) and conducting a precise household census, including their assets and also, delineating projects time schedule, inclusive stakeholders' participation, financing socio-economic costs, as well as utilizing professional consultancy [35], [15].

At best, slum resettlement is done by an agreement with dwellers through community participation [37]. A few aspects of the resettlement process include: (1) involving the affected people, (2) communities have to be organized, (3) information about the resettlement, (4) making use of the best practices from, (5) other cities/countries, (6) surveying the communities, (7) preparing the new plan, (8) selecting the new site, (9) preparing the new site and moving, and (10) organizing the move [35]. In all these phases, the target community participation is essential [38]. Other cross cutting paramount issues to be considered are; provision of affordable housing and infrastructures, safety and security, habitability, accessibility, supplying rental units for low-income people, security of tenure, and taking into account the needs of vulnerable groups. The non-participatory and large-scale resettlements may impose non-compensable negative impacts [35]. Thus, resettlement projects in their best practices should rely on consensus and collaboration of the target community [2]. In assessing Bangkok resettlement projects, Viratkapan and Perera (2006) found out that among the three stages of eviction, transition and consolidation of the target community, the last stage is the most important one for the project success. They emphasized on the specified actions in terms of enabling local community 
leadership, Non-Governmental Organizations (NGOs) and Community-Based Organizations (CBOs), especially at the consolidation stage [16].

\section{METHODS AND DATA}

\subsection{Data and criteria}

This research was the result of an original study on MRP resettlement project impacts which had no prior studies. This research was conducted between 2014 and 2016 in Ahvaz city. The origin site for the relocated community wasKaroon (Fig. 1), a slum, and the planned housing complex was called Sepidar (Fig. 2). Having considered the literature reviews of UNHabitat (1991 \& 2008a), World Bank (2004), Davidson et al. (1995), Cernea (1988) as well as studies of ATA (2014) and UDRO (2008), the main criteria in this study included:

a). Environmental factor: average land slope; percentage of so many on over 30\% slope and percentage of houses at the risk of landslide/slump in origin site. b). Housing and physical factor: Land use diversity; cleanliness and beauty of the neighbourhood according to residents; land acquisition and security of tenure; housing density and construction quality; percentage of durable houses; percentage of completed facade buildings; percentage of so many under $150 \mathrm{~m}^{2}$ area.

c). Basic infrastructures factor: Land use per capita for green space, sport and recreational facilities, and medical services; access to waste disposal services; percentage of available public transportation; number of schools per 100 residents; percentage of households with electricity, gas, telephone, piped water, sanitation facilities, waste disposal services and improved roads.

d). Economic factor: Rate of employment and unemployment; loan affordability; percentage of needy people; ratio of 3 top income deciles to 3 lowest deciles.

e). Social factor: Percentage to which households feels secure, having hope for better future, and enjoying calmness according to their views; religious facilities per capita; level of new settlers' satisfaction with resettlement.

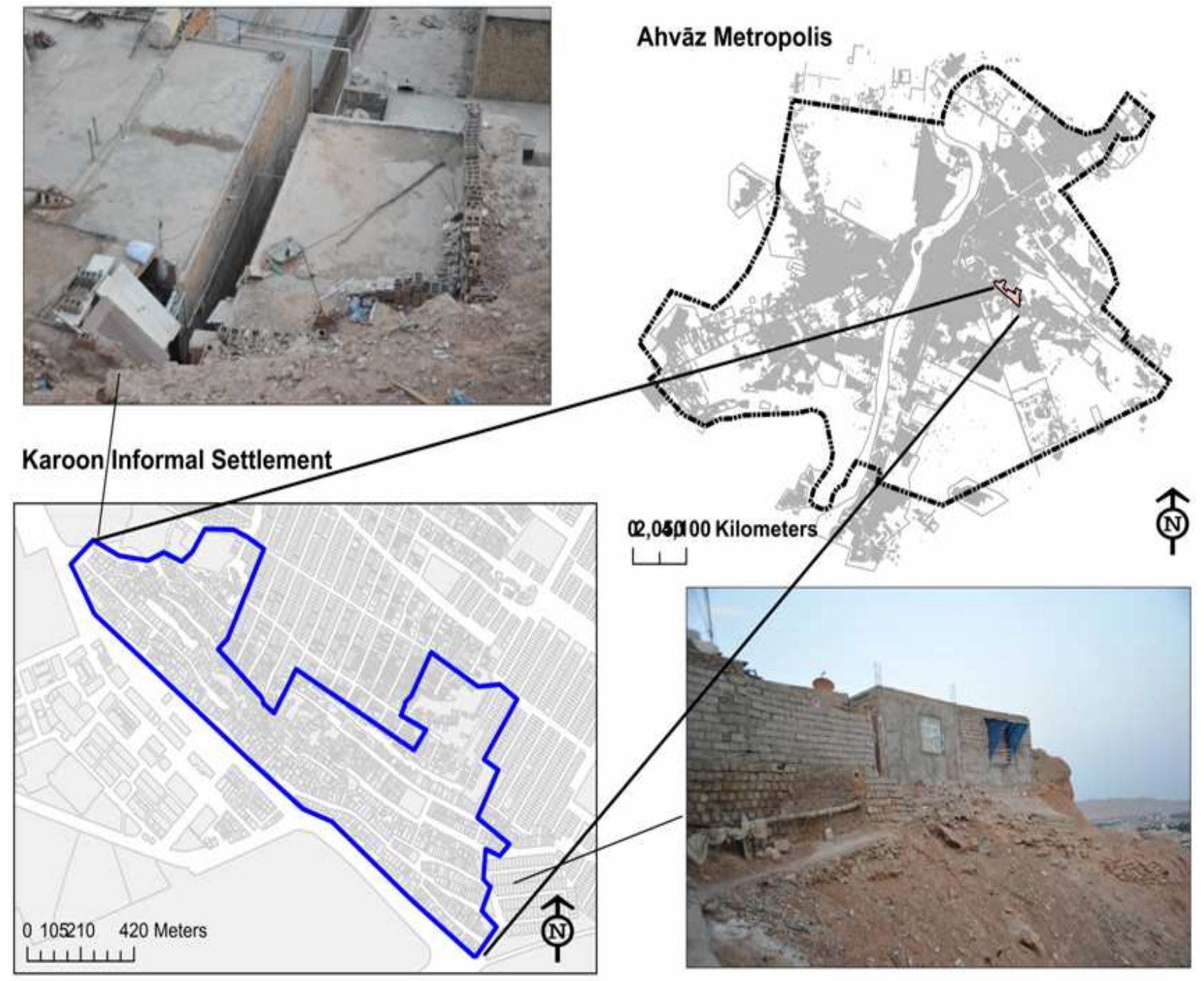

Fig. 1. Karoon (origin) neighborhood. 


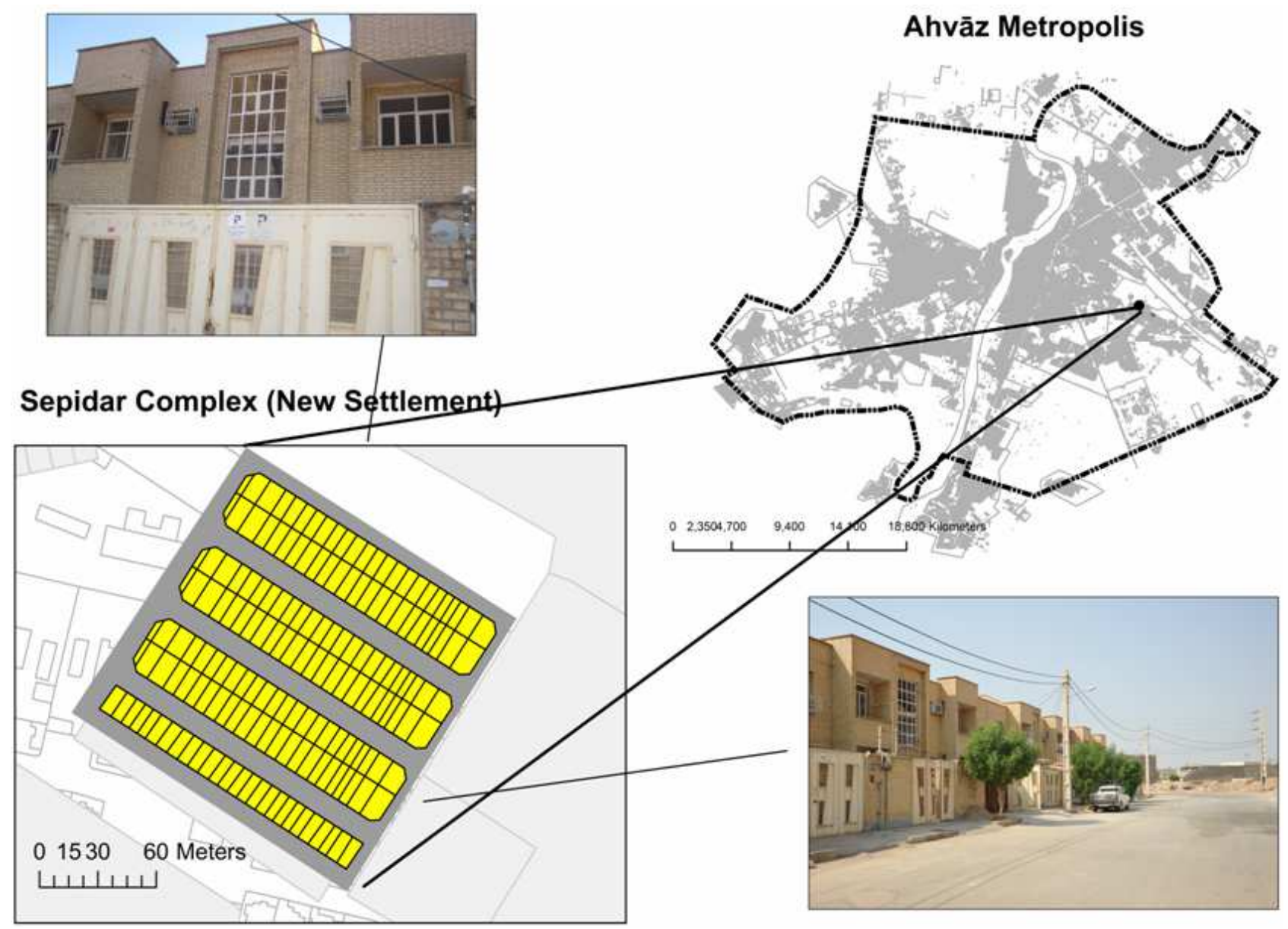

Fig. 2. Sepidar housing complex, MRP.

The study was carried out in a difficult and time-consuming situation due to lack of formal information, and official unwillingness to portray the outcomes of MRP. However, at the first stage, secondary data for MRP was collected from the available official documents of Ahvaz municipality reports, internal documents of Development and Housing Organization of Khuzestan Province, Slum Rehabilitation Unit of Khuzestan Province at Road and Urban Planning Department, and Khuzestan Housing Foundation of Islamic Revolution (KHF).

Primary data was collected through interviews with MRP directors and managers (date: 06/05/2016), as well as conducting purposive sample survey for 35 relocated households (out of a total of 157 households that relocated to the new site or Sepidar Neighbourhood in the first stage of MRP in 11 June, 2016.

The survey was conducted by trained local facilitators. Statistical Package for the Social Sciences 'SPSS' software was used to analyse the results, and Super Decision software was used to assess the impact of MRP on the described criteria. Finally, the realization of MRP goals and objectives were calculated by $G A M$ and COWS methods. Also, based on studies of ATA consultants for Ministry of Road and Urban Planning
[9], thematic maps were drawn by Arc GIS 10.5 software. In the following, GAM andCOW Stechniques are briefly described.

\subsection{Techniques}

\subsubsection{The 'GAM' technique}

The Goals-Achievement Matrix (GAM) was invented in 1968 by Morris Hill. This technique was used for decades in many researches because of its simplicity and transparency. This method is used to determine the degree of actualizing plans, implementing programs and project goals. In this method, criteria are used to measure the degree of the goals actualization. These criteria could be quantitative or qualitative. Each of the criteria should be of important and weight. The importance of the criteria could be between o to 100 and the weight of the criteria is between $o$ and 4 . This is depended on the choice of the method of weighting by the researcher or expert [50]. Different methods such as the Delphi method, the Analytical Hierarchy Process (AHP) or Analytical Hierarchy Process (ANP) method can be used to determine the weight of the criteria. After weighing the 
importance of the criteria, weighted matrix is obtained. The output of this matrix is computed in the GAM method formula. The final result that is shown as a percentage (between o and 100), indicates the extent to which the goals were realized or the likelihood of them being implemented in a program or project [51], [52]. In $G A M$ technique, Sensitivity Analysis $(S A)$ is used to measure the validity of the results and final decision making. $S A$ measures the extent of the impact of project goals from the criteria of evaluation. In this research, SA was used to determine the extent to which each of the criteria impacted on the objectives of the MRP project (Table 3). To determine the weight of the criteria, the $A H P$ method was used in Expert Choice software.

\subsubsection{The 'COWS' technique}

The "Criteria, Options, Weight, Score (COWS)" technique was invented by Stuart Pugh in 1981. COWS is a simple way to rank a limited number of alternatives based on specific criteria [53]. In this method, the criteria and options are determined and the weight of the criteria is determined by the researcher or experts. This weight can range from o to 4 [54]. In this research, the COWS method was used to rank the feasibility of the goals of the MRP project. Integrating this method with the GAM technique helped in the ranking of options based on criteria (Table 4). In fact, the COWS method is used for the final ranking.

Table 1. The context, approach, and implementation arrangement for MRP.

\begin{tabular}{|c|c|}
\hline Issue & Description \\
\hline Research and survey & Hastily and incomprehensive studies by KHF \\
\hline Upgrading approach & Demolition, replacement, prevention of substitute residents in Karoon \\
\hline Institutional arrangement & Establishing government committees with authority over local institutions \\
\hline Implementation phases & Acquiring slums, building new houses, demolishing slums \\
\hline $\begin{array}{l}\text { Local community } \\
\text { participation }\end{array}$ & No active participation assumed, mainly without negotiation power \\
\hline Financial mechanism & $\begin{array}{l}37 \% \text { by government grants, } 63 \% \text { by residents (Including the price of their slums and bank loan and } \\
\text { municipality infrastructure costs). }\end{array}$ \\
\hline Social institutions & No institutionalization prepared. Only local leaders co-opted for public relations. \\
\hline Assignment & On the basis of preliminary transfer license for households and the final approval of MRP committee \\
\hline Plan for original site & Total demolition and transferring the site to green space \\
\hline Project achievements & Resettlement of 157 households and municipal ownership of the original site \\
\hline
\end{tabular}

Table 2. Assessment of MRP impacts on living environment.

\begin{tabular}{|c|c|c|c|c|c|}
\hline \multirow[t]{2}{*}{ Factor } & \multirow[t]{2}{*}{ Criteria } & \multicolumn{4}{|c|}{$\begin{array}{l}\text { Resettled community situation in comparison with previous } \\
\text { situation }\end{array}$} \\
\hline & & Quite better & Mildly better & No difference & Worse \\
\hline \multirow{6}{*}{ Environmental } & Slump \& falling rocks risk & $\bar{x}$ & & & \\
\hline & Pollution & $x$ & & & \\
\hline & Land use diversity & & & & $x$ \\
\hline & Community cleanness \& beauty & $x$ & & & \\
\hline & Security of tenure & $x$ & & & \\
\hline & Land use per capita & & & & $x$ \\
\hline \multirow{4}{*}{ Physical } & Public transportation access & & & $x$ & \\
\hline & Educational facilities access & & & & $x$ \\
\hline & Public infrastructures quality & & $x$ & & \\
\hline & Housing quality & & $x$ & & \\
\hline Infrastructure & Electricity, water, gas, sanitation, etc. & & $x$ & & \\
\hline Public spaces & Park, community center $\&$ public square & & & & $x$ \\
\hline \multirow{3}{*}{ Economic } & Employment & & & $x$ & \\
\hline & Household income & & & $x$ & \\
\hline & Household costs & & & & $x$ \\
\hline \multirow{3}{*}{ Social } & Housing density & & & $x$ & \\
\hline & Security and safety & & $x$ & & \\
\hline & Place belonging & & $x$ & & $x$ \\
\hline
\end{tabular}


Involuntary Resettlement: From a Landslide-Affected Slum to a New Neighbourhood.

Case Study of Mina Resettlement Project, Ahvaz, Iran

Journal Settlements and Spatial Planning, vol. 9, no. 1 (2018) 11-24

Table 3. Calculation of performance sensitivity analysis.

\begin{tabular}{|c|c|c|c|c|}
\hline Factor & $\begin{array}{l}\text { Weight of } \\
\text { Criterion }\end{array}$ & $\begin{array}{c}\text { Impact Factor between } \\
+/-100 \\
\text { (in percent) }\end{array}$ & $\begin{array}{l}\text { Project Impact } \\
\text { Importance }\end{array}$ & $\begin{array}{l}\text { Type of } \\
\text { Impact }\end{array}$ \\
\hline Environmental & 0.493 & +70 & High & Positive \\
\hline Physical & 0.268 & +52 & Medium & Positive \\
\hline $\begin{array}{l}\text { Infrastructure \& Public } \\
\text { Facilities }\end{array}$ & 0.117 & -20 & Low & Negative \\
\hline Economic & 0.64 & +35 & Low & Positive \\
\hline Social & 0.58 & -30 & Low & Negative \\
\hline
\end{tabular}

Table 4. Evaluation of goals achievement with GAM and COWS methods.

\begin{tabular}{|c|c|c|c|c|c|c|c|c|c|c|c|c|c|c|c|c|c|c|c|c|}
\hline Factors & \multicolumn{5}{|c|}{ Environmental } & \multicolumn{5}{|c|}{ Physical } & \multicolumn{5}{|c|}{ Economic } & \multicolumn{5}{|c|}{ Socio-Cultural } \\
\hline \multirow[b]{3}{*}{$\begin{array}{c}\text { General } \\
\text { Goals }\end{array}$} & \multicolumn{5}{|c|}{$\alpha_{1}=50$} & \multicolumn{5}{|c|}{$\alpha_{1}=\mathbf{3 0}$} & \multicolumn{5}{|c|}{$\alpha_{1}=5$} & \multicolumn{5}{|c|}{$\alpha_{1}=5$} \\
\hline & 0 & 1 & 2 & 3 & 4 & 0 & 1 & 2 & 3 & 4 & 0 & 1 & 2 & 3 & 4 & 0 & 1 & 2 & 3 & 4 \\
\hline & 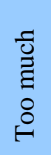 & 3 & 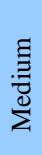 & $\stackrel{\tilde{E}}{\Sigma}^{\bar{\Sigma}}$ & 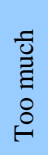 & ஜ̈ & 3 & 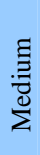 & $\stackrel{\tilde{g}}{\Sigma}$ & $\begin{array}{l}\overline{\tilde{O}} \\
\tilde{E} \\
8 \\
8\end{array}$ & 气̃ & ב్ & $\begin{array}{l}\text { 䲶 } \\
\sum_{\Sigma}^{0}\end{array}$ & $\sum_{\Sigma}^{\bar{\Xi}}$ & $\begin{array}{l}\frac{\tilde{0}}{0} \\
\stackrel{\Xi}{\Xi} \\
8 \\
0\end{array}$ & ஜ̇ & 30 & 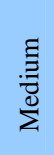 & $\sum_{\bar{c}}^{\tilde{g}}$ & $\begin{array}{l}\text { Uే } \\
\text { Ẽ } \\
8 \\
0\end{array}$ \\
\hline $\mathbf{1}^{\text {st }}$ Goal & & & & & + & & & & + & & & + & & & & & - & & & \\
\hline $2^{\text {nd }}$ Goal & & & & & + & & & & & + & & + & & & & & & + & & \\
\hline $3^{\text {rd }}$ Goal & & + & & & & & + & & & & & + & & & & & - & & & \\
\hline Sum & & +1 & & & +8 & & +1 & & +3 & +4 & & +3 & +1 & & & & -2 & +1 & & \\
\hline
\end{tabular}

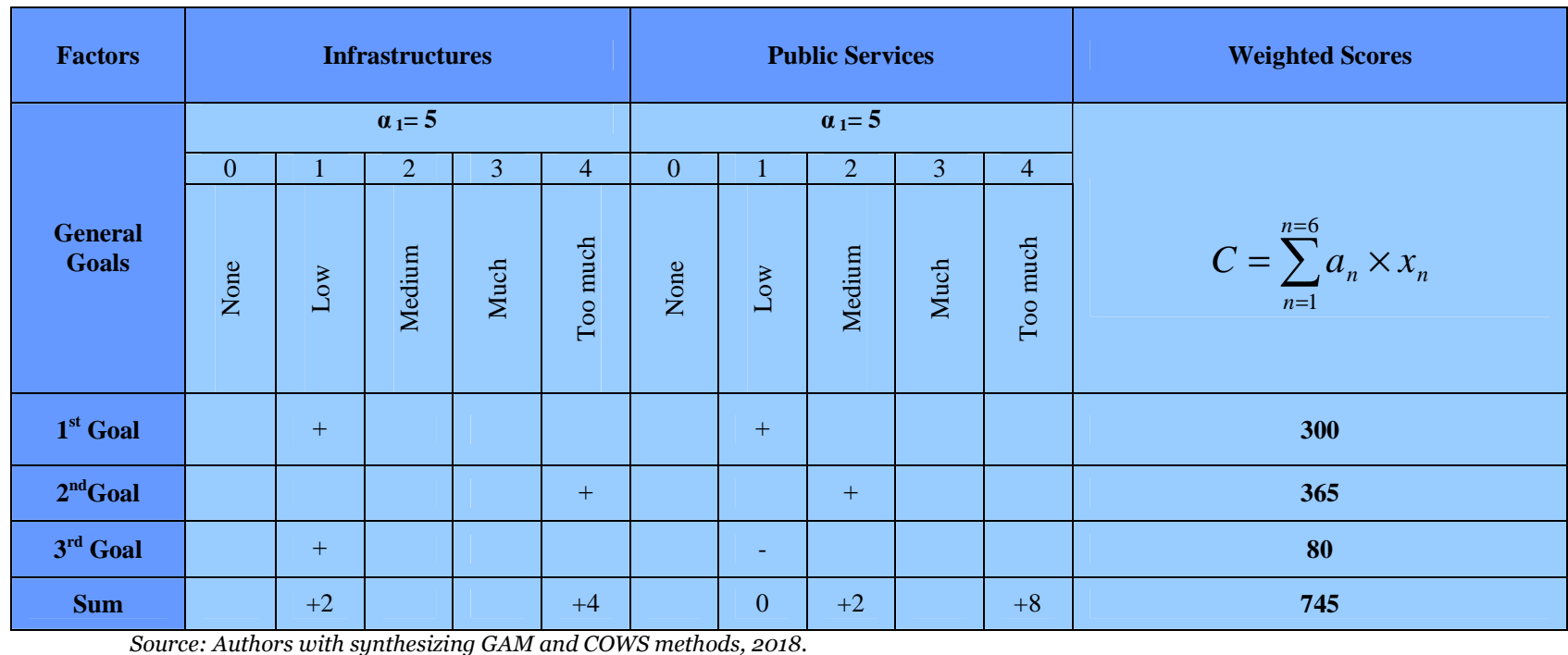

\section{RESULTS AND DISCUSSION}

\subsection{Background to Karoon and MRP}

Karoon is the name of a slum with about 14,000 residents and an area of 46 hectares within the eastern part of Ahavaz city. The establishment of this neighbourhood dates back to before the 1960s; however, its rapid growth occurred between 1961 and
1980 [9], [11]. In 2003 before MRP started, most of the residents were low income earners with an average of 116-dollar monthly income. $80 \%$ had no access to clean water and electricity services. $60 \%$ of the residents lacked access to telephone line and 90\% lived in nondurable houses without land title [43]. Karoon took the form of steeply hills with clay formation and slippery rock layer. Despite the implementation of MRP, our GIS map calculation showed that over $40 \%$ of 
241 parcels were still susceptible to slump and landslide (Fig. 3 and Fig. 4). Dilapidated houses, shortage of public services spaces, particularly for children and women, unemployment and environmental pollution were the main prevalent issues [9], [11]. From 1997 to 2003, a number of houses were demolished due to sudden and heavy rains which in turn caused landslide and human casualties in Karoon [44]. Before this happened, according to Ahvaz master plan, this neighbourhood was supposed to be green space and demolition and forced eviction was in the agenda of consultant [45]. Thus, relocation of local community was in the municipality program which was pursued seriously after the said casualties.

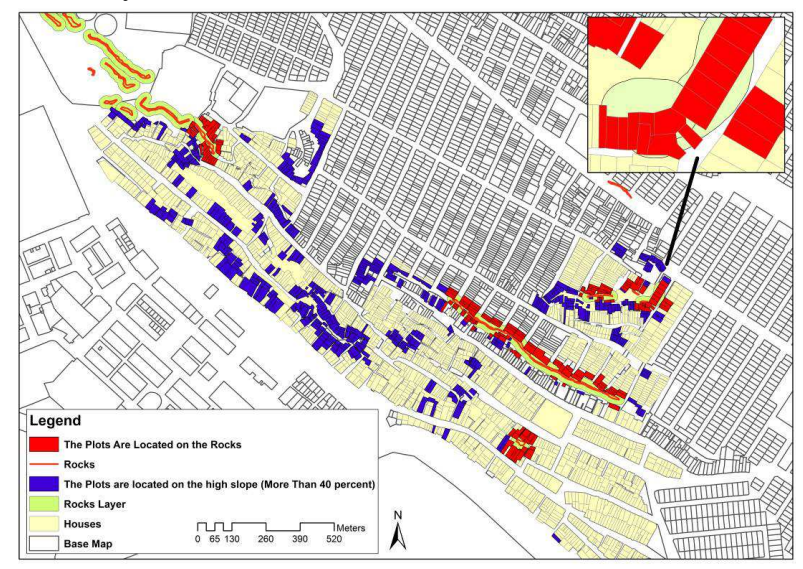
falling rocks.

Fig. 3. Housing units with high risk of slump and
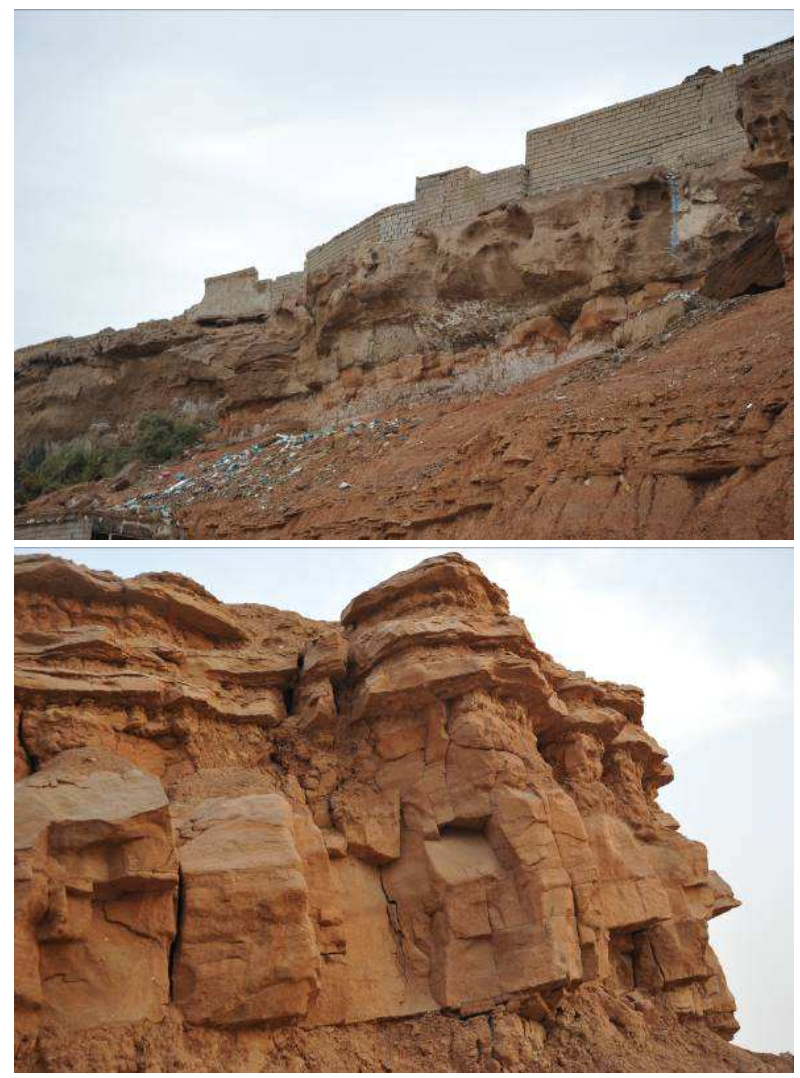

Fig. 4. Karoon houses located on steep hills susceptible to landslide.
In 2004, Khuzestan governorate established an MRP implementation arrangement (Institutional Structure) and set up committee with members from province institutions and a few local trustees to steer and implement the project (Fig. 5).

The committee decided to displace those households with most risks to another location. The main objectives were adopted as: (a) building appropriate housing units in a new site, (b) saving the households exposed to landslide and slump, and (c) gaining local community satisfaction. They signed a contract in March 2005 with Khuzestan Housing Foundation of Islamic Revolution (KHF) to plan the project and implement it. This foundation was a government institution and with the assistance of other local departments (that is, province, county, and district governorates, and municipality of Ahvaz) and trustees, did the inventory of Karoon and identified the household required to be displaced at first. The identification report was submitted to MRP committee in October 2005. In the report, 153 plots of land with 157 households from Karoon neighbourhood were prioritized. A great majority of them were low-income earners and migrant [44].

Thereafter, by an agreement with Housing and Urban Planning Organization of Khuzestan, a new site of 2.3 hectare at $1.5 \mathrm{~km}$ distance from Karoonwas allocated for the new place. The construction of 224 units on a site called Sepidar was contracted out to a semi-public firm named Khuzestan Housing Development Company in 2005. The additional units were allocated to other displaced households from other slums in Ahvaz city. It should be mentioned that the site selection as well as the new housing design were not consulted with the selected households for resettlement (Interviews with Sepidar residents 06/11/2016). In spite of the good progress of the Sepidar construction at the beginning, the project ran quite behind the schedule due to financial deficiency, uncoordinated provision of public infrastructures and difficulties in relocation management of Karoon community. Finally, Sepidar was completed in November 2008 (Interviews with Sepidar directors, 06/05/2016).From March 2009, KHF started the assignment of new housing units at Sepidar. At the same time, Ahvaz municipality, Khuzestan governorate, and housing bank, each undertook part of the costs of the site and services provided in the new site and the rest, $63 \%$ of the house prices were the share of the relocated residents. Table 1 summarizes the activities performed during the implementation of MRP. About one third of the targeted household for MRP were tenant, being construed as not having right of tenure to benefit from the MRP supports. These people, who were mostly the neediest, were eliminated from the project and no solution was substituted to salvage their homelessness. $80 \%$ of the relocated households were poor with less 
than 3 million Rials (US\$100) monthly income in 2009. Also, $13 \%$ of the household breadwinners were unemployed [44-46-43-9] and Interviews with MRP Directors in 2016.

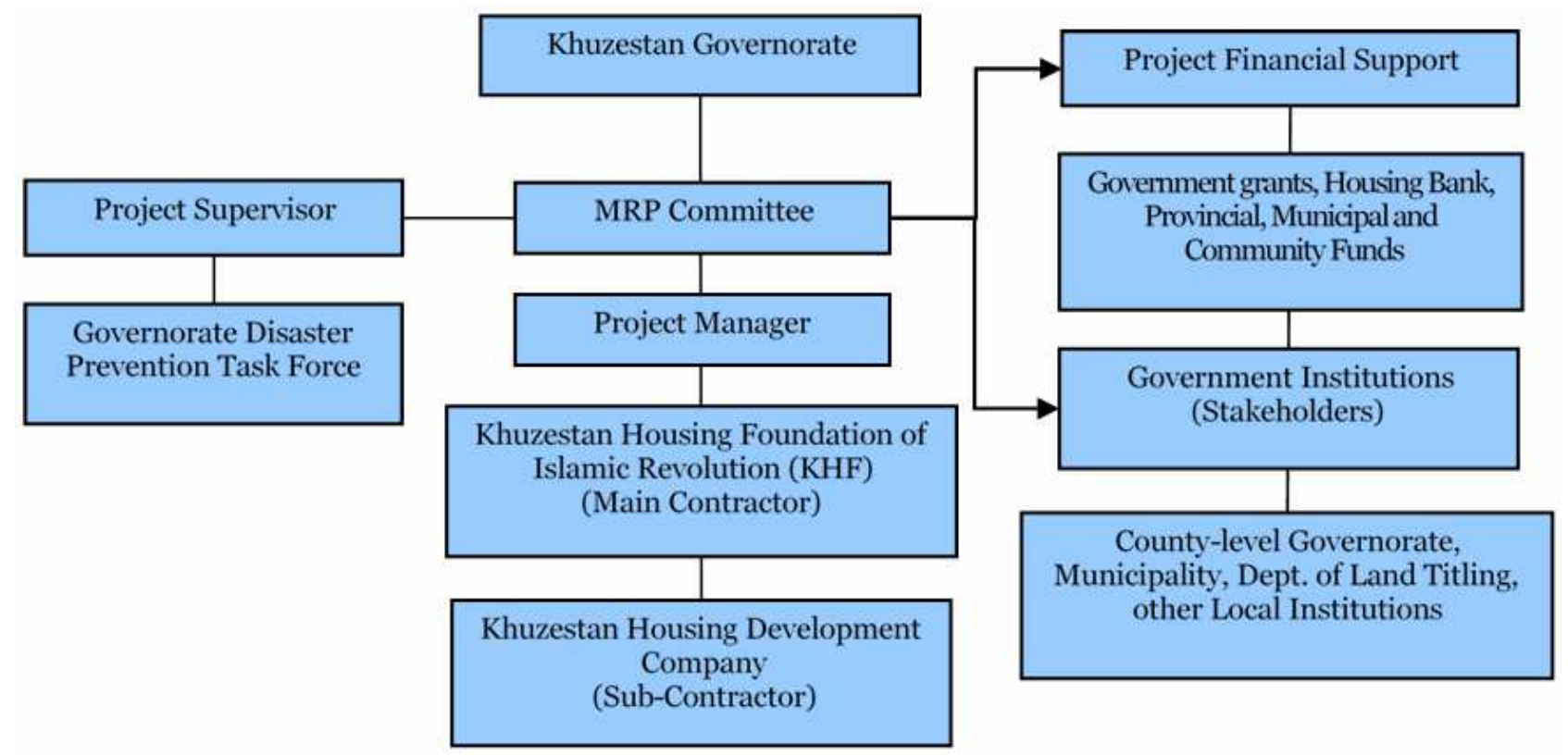

Fig. 5. Implementation arrangement of MRP.

MRP costs more than $\$ 3,562,500$ in total for all stakeholders till the end of 2009. The output of MRP was 224 units with an average built of $55 \mathrm{~m}^{2}$ for each. After this experience, constructing another 5400 houses with the state subsidy up to $\$ 220$ million for relocation of the same number of households from slums was in a province-wide program which has been going on still [13].

\subsection{MRP impact on local community}

In surveying the existing situation in Sepidar neighborhood, it was demonstrated that green space and public services land use were not allocated. Moreover, access to public transportation and other modes as well, were exacerbated. The possibility for retailing and commercial activities was eliminated in Sepidar. There is no educational facility for children. Some of the infrastructures built were not technically appropriate. For example, wastewater and rainwater do not drain well from street surface. The sizes of housing units are smaller as compared to the left-behind units and lack diversity and collective identity in the neighborhood design (e.g., row housing without welldefined public spaces). Functional relations in the new units do not adapt to the households' culture (e.g., residents change the lavatory in their apartment to den and rebuild it by the corner of the front yard) (Fig. 6).

The results of our survey (2016/11/06) and the analysis of criteria' weight and "head to head" sensitivity in Super Decision Software revealed that the environmental, physical, and economic sectors with values of 70,53 , and $35 \%$ consecutively, were positive changes at Sepidar as compared to Karoon (Tables 2 and 3).
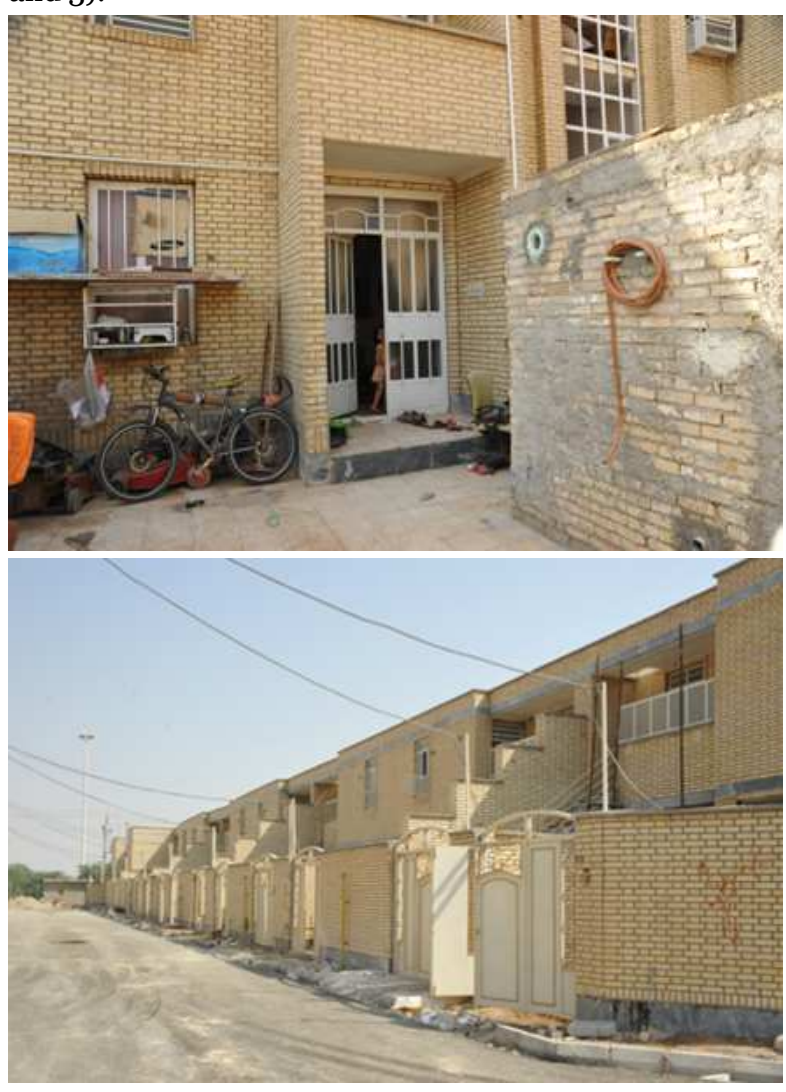

Fig. 6. Sample of Sepidar row housing for MRP. 
Households' economic situation was better due to the higher price of new houses; but they had difficulty in paying the instalment loans. From social viewpoint, fulfilling the needs of old people, children, and extended families were worsened as a result of living in Sepidar. Children lost their self-built playing grounds separate from traffic; old people lost their memorable spaces that they had a sense of belonging; and women lost spaces that they felt secure under community watch (Surveying 2016/11/o6). The results of weighting demonstrated that in sum, visual/objective factors with value of 0.72 were quite better in Sepidar than Karoon with value of 0.28 . This is mostly due to the elimination of landslide risk. Results of data analysis on Analytical Network Process method showed that in terms of social situation and access to infrastructure, the condition in the new site (Sepidar Complex) was worse than Karoon settlement (Fig. 7).
The concluding remarks of this section were the varied impact of MRP in terms of volume and type, considering different factors in this research.

\subsection{Satisfaction of local community from MRP}

Our study showed that close to $40 \%$ of the displaced households were satisfied with MRP and the others were dissatisfied. For the first group, the main reasons for their satisfaction were as a result oftheir benefitting from a better quality of housing and environment and exclusion of imminent natural risks (Figure $7 \mathrm{~A}$ and $\mathrm{B}$ ).

Most of the dissatisfied group stated that, the smallness of their housing units, lack of neighbourhood services, disintegration of community relations, high monthly payment of loans and monotonous building types, were the reasons for their discontent.

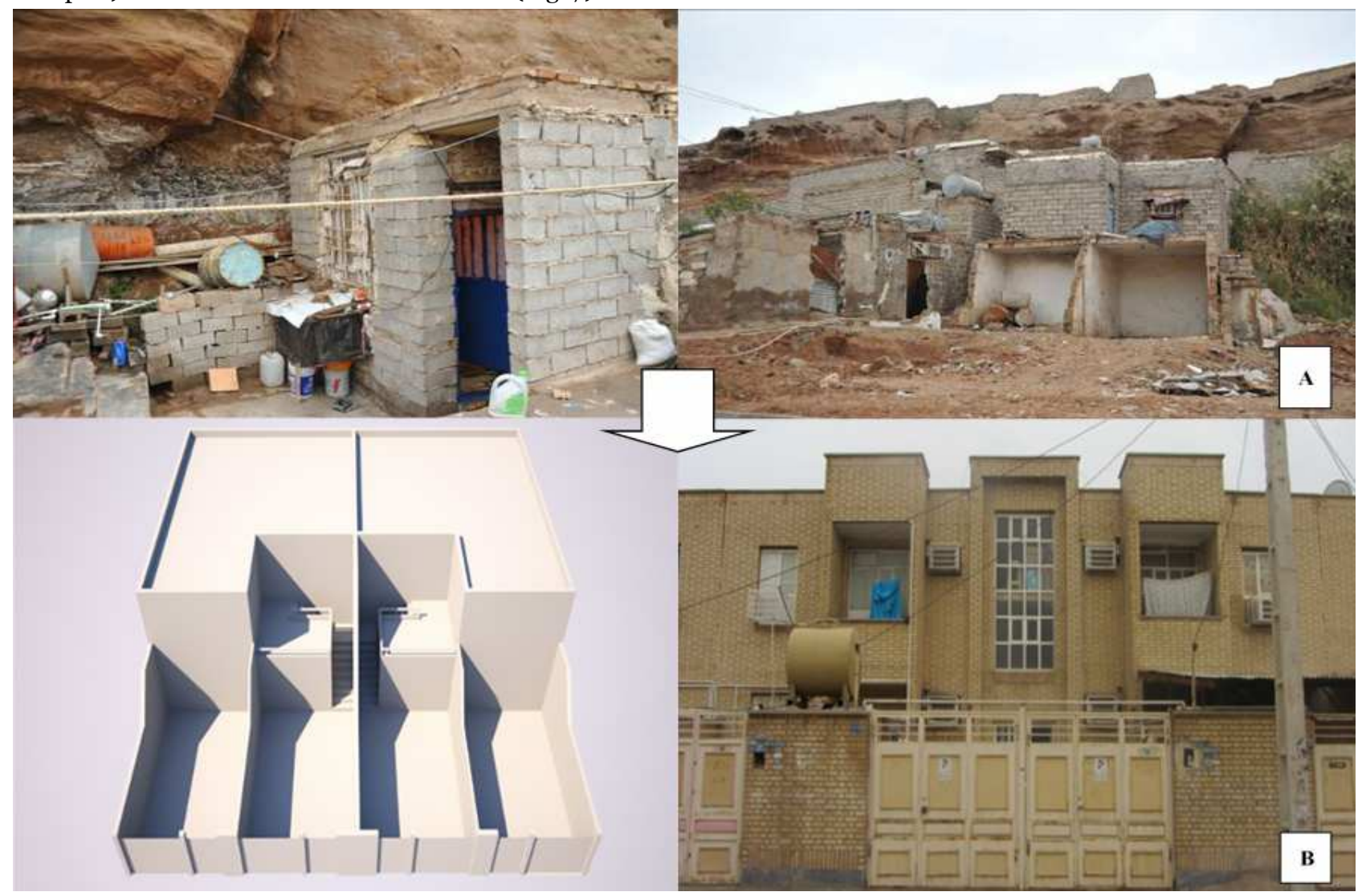

Fig. 7. (A) Housing units of Karoon, (B) Later resettlement to new site.

As a result, about $30 \%$ of the newly settled households in Sepidar moved out in the last 5 years and rented out their units. Though this movement was notrecorded, it was reported that most of them have returned to other informal communities of Ahvaz. They benefitted from the rent income which is higher than what they pay at slums. The calculation of Spearman's correlation between housing situation and dissatisfaction with MRP revealed 0.609 with a significance level of 0.000 which was the highest level from housing point of view (Survey on 2016-11-06).

\subsection{Levels of goals achievement in MRP}

Three general goals of appropriate housing provision, avoiding slump and rock falling hazards, and fulfilling local community satisfaction, were defined in MRP. Noting the said survey and studies, $G A M$ was employed as a multi-criteria technique to expose the quantitative level of accomplishing the goals. The results pointed out $75,91.25$, and $20 \%$ values respectively for the 3 mentioned goals. In total, MRP had a value of $62.08 \%$ from success view (Table 4 ). In 
Table $4, x_{n}=$ weight ( 1 to 4 ), $a_{n}=$ the coefficient of the importance (o to 100), and $\mathrm{n}$ is the number of criteria. Sign + represents positive impact, o and - represent none and negative impact. If 100 is assumed for full

Eq. 1

Achievement level of goal one: achievement of each goal and 400 for weighted score of criteria and 1200 for sum of weighted scores, then the calculations are as follows:

$C=\sum_{n=1}^{n=6}=\frac{(+4 \times 50)+(+3 \times 30)+(+1 \times 5)+(-1 \times 5)+(+1 \times 5)+(+1 \times 5)}{6}=\frac{300}{6}=50=\left(300 \times \frac{100}{400}\right)=75 \%$

Achievement level of goal two:

$C=\sum_{n=1}^{n=6}=\frac{(+4 \times 50)+(+4 \times 30)+(+1 \times 5)+(+2 \times 5)+(+4 \times 5)+(+2 \times 5)}{6}=\frac{365}{6}=60.83=\left(355 \times \frac{100}{400}\right)=91.25 \%$

Achievement level of goal three:

$\mathrm{C}=\sum_{\mathrm{n}=1}^{\mathrm{n}=6}=\frac{(+1 \times 50)+(+1 \times 30)+(+1 \times 5)+(-1 \times 5)+(+1 \times 5)+(-1 \times 5)}{6}=\frac{80}{6}=13.33=\left(80 \times \frac{100}{400}\right)=20 \%$

Total achievement level:

$$
\text { Total } C=\sum \sum_{n=1}^{n=6}=300+355+80=\frac{745}{6}=124.16=\left(745 \times \frac{100}{1200}\right)=62.08 \%
$$

The findings of this study confirmed the findings of UN-Habitat (2014), Purnomo et al. (2013) regarding the high cost of resettlement plans [3], [20]. Also, Kapse et al. (2012) beliefs supported that without deep and comprehensive studies prior to resettlement, the newly resided people will return to their previous neighbourhoods [19]. However, Mandhyan and Patel (2014) statements were partially confirmed. They were right in terms of the burden of high cost of displacement on low income people in MRP but were not supported on the ground that the new houses have less market value than the left behind houses [23]. In the same manner, like the findings of Gebre (2014), different impacts of resettlement project can be inferred on the development factors, whereas MRP was the most unsuccessful from the social point of view [18]. The findings also proved the result of studies by World Bank (2010, 2011), Nampungu and Kasabiiti (2009), and Singh (2013) on negative impact of resettlement for children and aged people [31], [24]. At last, the claims by UN-Habitat (2004, 2009), that resettlement projects were doomed to fail if the affected communities do not completely embrace participation in the process from start to finish (not just for the financial issues) was verified [2], [47].

\section{CONCLUSION}

The main objective of this study was to evaluate the actualization of the MRP goals in Ahvaz city. The results gotten from using the GAM method for evaluating
MRP, pointed out that there were different impacts on the target community, mainly in environmental criteria. The implementation of MRP eliminated the risks of slump and falling rocks and also resulted in the construction of durable structures; nevertheless, the new structures were not appropriate, due to negligence of the cultural patterns and affordability of the low-income residents. In addition, building houses were not accompanied by establishing social services and community spaces. These were the principal reasons for community dissatisfaction at the new site. Therefore, despite the high achievement of environmental and physical goals, MRP was not successful in terms of socioeconomic goals, which may lead the project towards final failure. A notable portion of resettled households in Sepidarwere witnessed to have left their new houses and returned to unknown informal sites. In conclusion, this study emphasized the importance of social, economic, and environmental ex-post evaluations in determining the success of resettlement, if necessary. During the entire process of planning and implementation, local community participation should be established with binding decision power to avoid outsider's faults (particularly in terms of considering lifestyles and quality of design). To this end, inclusive institutional arrangement consists of all stakeholders in connection to government and public sector, especially CBOs, NGOs, and local leaders, should be taken into account before starting the implementation.

The findings of this study may help policymakers and urban planners to improve the 
allocation of their resources and methods of urban slums regularising projects. Future studies can focus more closely on the social, physical, environmental, and economic impacts of resettlement projects. Those studies can explore ways to reduce the negative consequences of slum resettlement projects.

\section{ACKNOWLEDGMENTS}

The authors appreciate Ahvaz Municipality (district 7), Disaster Task force in Khuzestan Governorate, Khuzestan Branch of Road and Urbanization Ministry, Urban Development and Reconstruction Company, and Amayesh and Toseh Alborz consultants for their help in preparing this study.

\section{REFERENCES}

[1] World Health Organization (WHO) (2015), Slum Residence: Situation and Trends. Glob Heal Obs. URL:www.who.int/gho/urban_health/determinants/sl um_residence_text/en/. Accessed March 19, 2018.

[2] UN - Habitat (2004), The Challenge of Slums: Global Report on Human Settlements 2003, Management of Environmental Quality: An International Journal, Volume 15, Issue 3, pp. 337-338, https://doi.org/10.1108/meq.2004.15·3.337.3

[3] UN-Habitat (2014), Housing \& Slum Upgrading. UN-Habitat. URL: https://unhabitat.org/urbanthemes/housing-slum-upgrading/. Accessed June 3, 2018.

[4] Statistic Center of Iran (2014), Estimation of the population of Iran. URL: https://www.amar.org.ir/. Accessed June 3, 2018. [In Persian]

[5] Urban Development and Revitalization Organization (UDRO) (2014), $2 O$ million of population in the urban Slums of the country. URL: http://udrc.ir/. Accessed April 3, 2018 [In Persian].

[6] Irandoost, K. (2009), Slums and the Myth of Marginality. Tehran: Tehran Municipality Publication. [Book in Persian]

[7] Sarrafi, M. (2008), Regularizing Slums in light of Good Governance in Iran. Haft Shahr, Volume 2, Issue 23-24, pp. 4-13. URL: http://www.haftshahr journal.ir/article_9569.html. Accessed April 4, 2018. [In Persian]

[8] Khouzestan Governorate (2015), About Khouzestan. URL: .https://ostan-khz.ir/Default.aspx? tabid=1595. Accessed June 1, 2018. [In Persian]

[9] Amayesh and Toseaye Alborz, (ATA) (2014), Feasibility Studies for Khuzestan Province Cities Slum Upgrading with Emphasis on House Promotion, (Internal Report). Tehran, UDRO, National Taskforce on Slum Upgrading Library, Internal Hardcover report. AccessedMay 7, 2017. [In Persian]
[10] Ahvaz Municipality (2014), Statistical Yearbook of Ahvaz Metropolis. URL: http://planning.ahvaz.ir/ Default.aspx?tabid=4179. Accessed April 3, 2018. [In Persian]

[11] Urban Development and Revitalization Organization (UDRO) (2008), Feasibility Studies on Ahvaz Slums Upgrading and enabling, Hardcover Report, Tehran. Accessed January 5, 2017. [In Persian] [12] Khuzestan Development and Housing Construction Company (OVM) (2014a), The Progress Report of 5400 Housing Plan of Khuzestan Province. Internal Hardcover report. Accessed January 5, 2017. [In Persian]

[13] Khuzestan Development and Housing Construction Company (OVM) (2014b), Reports on the Renewal Plan of War-affected people Houses in Slum Areas in Khuzestan province. Internal Hardcover report. Accessed February 6, 2013. [In Persian]

[14] Mc Donald, B., Webber, M., Duan, Y. (2008), Involuntary Resettlement as an Opportunity for Development: The Case of Urban Resettlers of the Three Gorges Project, China. Journal of Refugee Studies, vol. 21, issue 1, pp. 82-102. https://doi.org/ 10.1093/jrs/femo52

[15] Asian Development Bank (ADB) (1998), Handbook on Resettlement: A Guide to Good Practice. Asian Development Publication. Online version URL: https://www.adb.org.

[16] Viratkapan, V., Perera, R. (2006), Slum Relocation Projects in Bangkok: What Has Contributed to Their Success or Failure? Habitat International, vol. 30, issue 1, 1 March, pp. 157-174.

[17] Cavalheiro, D. C., Abiko, A. (2015), Evaluating slum (favela) resettlements: The case of the Serra do Mar Project, Sao Paulo, Brazil. Habitat International vol. 49, pp. 340-348. DOI: 10.1016/j.habitatint. 2015.05.014.

[18] Gebre, H. A. (2014), The Impact of Urban Redevelopment-Induced Relocation on Relocatees' Livelihood Asset and Activity in Addis Ababa: The Case of People Relocated Arat Kilo Area. Asian Journal of Humanities and Social Studies, vol. 2, issue 1, pp. 4350. URL: https://www.ajouronline.com/index. php/AJHSS/article/view/719. Accessed on June 3, 2018.

[19] Kapse, V., Pofale, A., Mathur, M. (2012), Paradigm of Relocation of Urban Poor Habitats (Slums): Case Study of Nagpur City. World Academy of Science, Engineering and Technology. vol. 6, November 25, pp. 641-648.

[20] Purnomo, T. A., Hermawan. Hrmawan, H., Hardjanto, I. (2013), Slum Resettlement along Brantas Riverbanks Case Study at Malang City, East Java. J-PAL, vol. 4, issue 2, pp. 20-28. Online version retrieved from: http://jpal.ub.ac.id/index.php/jpal/ article/view/135/137. 
[21] Kearns, A., Mason, P. (2013), Defining and Measuring Displacement: Is Relocation from Restructured Neighbourhoods Always Unwelcome and Disruptive? Housing Studies, vol. 28, issue 2, pp. 177204. doi:10.1080/02673037.2013.767885.

[22] Arabindoo, P. (2011), Rhetoric of the 'slum', City, vol. 15, issue 6, pp. 636-646. https://doi.org/ 10.1080/13604813.2011.609002.

[23] Patel, S., Mandhyan, R. (2014), Impoverishment assessment of slum dwellers after offsite and on-site resettlement: a case of Indore. Commonwealth Journal of Local Governance, Issue 15, pp. 104-127. DOI: http://dx.doi.org/10.5130/cjlg. voio. 4065 .

[24] World Bank (2011), Integrating a child focus into poverty and social impact analysis. UNICEF World Bank guidance note. Washington, DC: World Bank. URL: http://go.worldbank.org/OSPTUYMV6o.

[25] Nampungu, P., Kasabiiti, D. (2009), The Impact of Involuntary Resettlement on Children; A Case Study of the International Development Association Funded Bujagali Hydropower Dam. https://consultations.worldbank.org/Data/hub/files/n aminyafinalreport.pdf.

[26] Singh, S. (2013), The Impacts of Urban Resettlement on Children the Impacts of Urban Resettlement on Children. https://docmh.com/theimpacts-of-urban-resettlement-on-children-pdf.

[27] Kleinhans, R., Kearns, A. (2013), Neighbourhood Restructuring and Residential Relocation: Towards a Balanced Perspective on Relocation Processes and Outcomes, Housing Studies, vol. 28, issue 2, pp. 163-176. DOI: https://doi.org/ 10.1080/02673037.2013.768001.

[28] Ramakrishnan, K. (2014), Cosmopolitan imaginaries on the margins: negotiating difference and belonging in a Delhi resettlement colony, Contemporary South Asia, vol. 22, issue 1, pp. 67-81. DOI: https://doi.org/10.1080/09584935.2013. 870976.

[29] Contractor, Q. (2008), Understanding the impact of involuntary slum resettlement on women's access to healthcare in Mumbai, India, Journal of Comparative Social Welfare, vol. 24, issue 2, pp. 153163. https://doi.org/10.1080/17486830802231131

[30] Read, J. C. (2014), Un-Settlement, Home Cultures, vol. 11, issue 2, pp. 197-218. https://doi.org/ 10.2752/175174214X13891916944670

[31] World Bank. (2010), Safer Homes, Stronger Communities: A Handbook for Reconstructing After Natural Disasters. World Bank. URL:http://hdl. handle.net/10986/2409.

[32] Price, S. (2009), Prologue: Victims or Partners? The Social Perspective in Development-Induced Displacement and Resettlement, the Asia Pacific Journal of Anthropology, Volume 10, Issue 4, 266-282. https://doi.org/10.1080/14442210903305821
[33] Choi, Y., Kim, H., Woosnam, K. M., Marcouiller, D. W., Kim, H. J. (2016), Urban resettlement in residential redevelopment projects: considering desire to resettle and willingness to pay. $\mathrm{J}$ Housing and the Built Environment, issue 31, pp. 213238. DOI 10.1007/s10901-015-9453-6.

[34] Zaman, M. (2002), Resettlement and development in Indonesia. Journal of Contemporary Asia, Vol. 32, issue 2, pp. 255-266. https://doi.org/ 10.1080/00472330280000161

[35] UN-Habitat (2008b), Quick Guide for the Policy Makers 4, Eviction: Alternatives to the Whole-Scale Destruction of Urban Poor Communities. UN-Habitat. Online version URL: https://unhabitat.org/books/ quick-guides-for-policy-makers-4-eviction-alternativesto-the-whole-scale-destruction-of-urban-poorcommunities/

[36] Luchi, K. (2014), Planning Resettlement After Disasters. Planning Resettlement After Disasters, Journal of the American Planning Association, vol. 80, issue 4, pp. 413-425. DOI: https://doi.org/10.1080/ 01944363.2014 .978353

[37] Abebe, G., Hesselberg, J. (2015), Community participation and inner-city slum renewal: relocated people's perspectives on slum clearance and resettlement in Addis Ababa, Development in Practice, vol. 25. issue 4, pp. 551-562. https://doi.org/10.1080 /09614524.2015.1026878

[38] UN-Habitat (1991), Evolution of Relocation Experience. Nairobi, UN-Habitat Publications. UNHabitat Publications.

[39] World Bank (2004), Involuntary Resettlement Sourcebook. The World Bank Publications. URL: http://documents.worldbank.org/curated/en/2066714 68782373

[40] UN-Habitat (2008a), Quick Guide for The Policy Makers 2, Low-Income Housing: Approaches to Help the Urban Poor Find Adequate Accommodation. URL: http://www.citiesalliance.org/node/2494.

[41] Davidson, F., Zaaijer, M., Peltenburg, M., Rodell, M. (1995), Relocation and Resettlement Manual: A Guide to Managing and Planning Relocation. Habitat International, Volume 19, Issue 1, pp. 1-147. https://doi.org/10.1016/0197-3975(95)90021-7.

[42] Cernea, M. M. (1988), Involuntary Resettlement in Development Projects: Policy Guidelines in World Bank-Financed Projects. Washington, DC: World Bank. [43] Ahvaz Municipality (2005), Report on Ahvaz City Marginality and Mina Project Progress. Ahvaz, Municipality of Ahawaz (In Persian). Accessed July 4, 2017.

[44] Ahvaz County Governorate (ACG) (2004), Report of the Land Slide Affected Houses of the Karoon Settlement in the City of Ahvaz. Internal Hard Cover Report in ACG Library. Accessed January 2, 2016. [In Persian] 
[45] Pajoohesh and Omran Consultants (1988), Report of Ahvaz Master Plan. Internal Hardcover Report in Ahvaz Municipality Library. Accessed on September 3, 2017. [In Persian]

[46] Khuzestan Housing Foundation of Islamic Revolution (KHF) (2005), Evaluation of the two phases of implementation the Karoon and ManbaeAab Slums Relocation Plan in Ahvaz. Internal hard cover report. Accessed December 21, 2016. [In Persian]
[47] UN-Habitat (2009), Sri Lanka Innovative Approaches for Involuntary Resettlement. UN-Habitat. URL: http://www.recoveryplatform.org/outfile.php?id =577\&href=http://www.recoveryplatform.org/assets $/ \mathrm{p}$ ublication/un\%2ohabitat\%2oresettlement\%20sri\%2ola nka.pdf. 